\title{
miR-125a-5p reverses epithelial-mesenchymal transition and restores drug sensitivity by negatively regulating TAFAZZIN signaling in breast cancer
}

\author{
DONGMEI LI ${ }^{1}$, LIMEI CHEN ${ }^{2}$, XIAOFANG ZHANG ${ }^{1}$, YANHUA WANG ${ }^{1}$, \\ CHUANSHENG HUANG ${ }^{1}$, JIANGLONG LI ${ }^{1}$, FEILONG HE ${ }^{1}$ and WENXING HE ${ }^{1}$
}

${ }^{1}$ Breast Cancer Center, The Affiliated Cancer Hospital of Nanchang University (Jiangxi Provincial Cancer Hospital),
Nanchang, Jiangxi 330029; ${ }^{2}$ Research Center for Differentiation and Development of TCM Basic Theory,
Jiangxi University of Traditional Chinese Medicine, Nanchang, Jiangxi 330004, P.R. China

Received December 3, 2020; Accepted July 16, 2021

DOI: $10.3892 / \mathrm{mmr} .2021 .12452$

\begin{abstract}
MicroRNA (miR)-125a-5p represses tafazzin phospholipid-lysophospholipid transacylases (TAFAZZIN) expression and inhibits the epithelial-mesenchymal transition (EMT) of ovarian cancer cells. EMT was found to have a crucial role in the acquisition of chemoresistance. Thus, the present study aimed to determine whether miR-125a-5p reverses EMT and restores drug sensitivity by negatively regulating TAFAZZIN in breast cancer. The expression of miR-125a-5p/TAFAZZIN and its association with chemotherapy response were determined in tissue samples from patients with breast cancer. Furthermore, the effects of miR-125a-5p on breast cancer cells were elucidated using cell proliferation and cell apoptosis assays. Then, the regulatory mechanism of miR-125a-5p in breast cancer was investigated by reverse transcription-quantitative PCR, western blotting, dual-luciferase reporter and RNA immunoprecipitation assays. The results demonstrated that miR-125a-5p inhibited the EMT of MCF-7/adriamycin (Adr) breast cancer cells, as well as decreased the proliferation and increased the apoptosis of breast cancer cells treated with Adr/docetaxel. In addition, miR-125a-5p downregulated the expression levels of TAFAZZIN, Transglutaminase 2, phosphorylated-AKT, $\mathrm{N}$-cadherin, vimentin and proliferating cell nuclear antigen, and significantly increased those of E-cadherin, cleaved caspase-3 and Bax in MCF7/Adr cells. Similar results were obtained with small interfering RNA-TAFAZZIN. Moreover, TAFAZZIN
\end{abstract}

Correspondence to: Dr Wenxing He, Breast Cancer Center, The Affiliated Cancer Hospital of Nanchang University (Jiangxi Provincial Cancer Hospital), 519 Beijing East Road, Nanchang, Jiangxi 330029, P.R. China

E-mail: hewenxingcjx@126.com

Key words: microRNA-125a-5p, tafazzin phospholipidlysophospholipid transacylases, drug resistance, epithelialmesenchymal transition, breast cancer was identified as a direct target of miR-125a-5p in MCF7/Adr breast cancer cells. In addition, increased miR-125a-5p expression was observed in breast tumors from patients exhibiting a chemotherapy response, and TAFAZZIN mRNA expression was elevated in patients with no chemotherapy response. Hence, miR-125a-5p expression was negatively correlated with TAFAZZIN mRNA expression in breast cancer tissues. All these data suggested that miR-125a-5p reverses EMT and restores drug sensitivity by negatively regulating TAFAZZIN in breast cancer and, therefore, has potential as a novel therapeutic target for this disease.

\section{Introduction}

In 2020 , there were $\sim 276,480$ new cases of breast cancer in the United States, and breast cancer was the leading cause of cancer-related death in women, thus seriously threatening women's physical and mental health (1). To date, the sequential administration of adriamycin (Adr) and docetaxel (Doc) is frequently used for neoadjuvant or adjuvant chemotherapy in breast cancer (2). Chemoresistance remains among the top challenges in current breast cancer treatment (3).

MicroRNAs (miRNAs/miRs) are a group of small non-coding RNAs that structurally consist of $18-25$ nucleotides and mediate important biological and physiological processes, such as the proliferation, growth, apoptosis, differentiation, invasion, migration, metastasis and chemosensitivity of several cancer types, including breast cancer (4).

miR-125a-5p has a controversial role in cancer progression. Recent evidence indicates that this gene inhibits proliferation and induces apoptosis in hepatocellular carcinoma cells (5). Moreover, miR-125a-5p is widely expressed in different tissues and cells, and is a suppressor in various cancer types (6). For example, miR-125a-5p may act as a tumor suppressor miRNA and a marker of prognosis and recurrence in head and neck squamous cell carcinoma (7).

In cancer cells, the Hippo pathway is tightly regulated by mechanical force, cell-cell contact and polarity, and is a central regulator that promotes tumor initiation and progression $(8,9)$. As the major downstream effector of the Hippo 
pathway, tafazzin phospholipid-lysophospholipid transacylases (TAFAZZIN) is involved in tissue homeostasis and tumorigenesis (10-12). As a biologically potent transcriptional coactivator, TAFAZZIN serves an important role in the development and sustainability of neoplasia (10). miR-125a-5p overexpression can repress TAFAZZIN expression to inhibit the epithelial-mesenchymal transition (EMT) of ovarian cancer cells (13). Furthermore, a decreased miR-125 expression promotes colorectal cancer cell proliferation and invasion, whereas miR-125 inhibits colorectal cancer cell proliferation and invasion by targeting TAFAZZIN (14).

Our previous study reported that Transglutaminase 2 (TG2) downregulation can reverse EMT and modulate the chemosensitivity of MDA-MB-231 breast cancer cells to Doc (15). However, the molecular mechanisms of resistance to drug (Adr/Doc) in breast cancer remain unknown. The present study aimed to determine whether miR-125a-5p suppresses EMT and reverses the drug resistance and restores the sensitivity to Adr/Doc of breast cancer cells by targeting TAFAZZIN.

\section{Materials and methods}

Cell lines and drugs. MCF-7/Adr breast cancer cells, authenticated by short tandem repeat, were obtained from Qingqi (Shanghai) Biotechnology Development Co., Ltd. Cells were grown in RPMI-1640 medium (Sigma-Aldrich; Merck KGaA) supplemented with 10\% FBS (Thermo Fisher Scientific, Inc.) and $1 \%$ penicillin/streptomycin $(10,000 \mathrm{U}$ penicillin and $10 \mathrm{mg}$ streptomycin) at $37^{\circ} \mathrm{C}$.

Direct and indirect assays were performed to detect mycoplasma contamination within MCF-7/Adr cell cultures $(16,17)$. Vero cells (mycoplasma-free cells; cat. no. GDC0029; China Center for Type Culture Collection) and B6yH4 cells (mycoplasma positive hybridoma cells; cat. no. GDC0017; China Center for Type Culture Collection) were used as negative and positive controls, respectively. MCF-7/Adr cell cultures were observed microscopically for mycoplasma colonies each week for $\geq 21$ days. Extracellular fluorescence under a fluorescence microscope indicated mycoplasma contamination. At an appropriate density $(6,000$ cells/well), the cells were seeded in 96 -well plates and incubated overnight at $37^{\circ} \mathrm{C}$ after mycoplasma detection. Adr and Doc samples were acquired from the Clinical Department of Jiangxi Provincial Cancer Hospital (Nanchang, China) and originally purchased from Zhejiang Hisun Pharmaceuticals Co., Ltd., and Jiangsu Hengrui Medicine Co., Ltd., respectively. Breast cancer cells were seeded into 96 -well plates $\left(6 \times 10^{3}\right.$ cells/well), incubated for $48 \mathrm{~h}$ at $37^{\circ} \mathrm{C}$, treated with Adr or Doc and classified into the following groups: Negative control (NC) group, miR group (transfected with miR-125a-5p), Adr/Doc group (treated with Adr or Doc) and miR/drug group (transfected with miR-125a-5p and treated with Adr or Doc). MCF7/Adr cells were initially treated with different concentrations $(0.625,1.25$, 2.5, 5, 10, 20 and $40 \mu \mathrm{M}$ ) of Adr or Doc and miR-125a-5p for $72 \mathrm{~h}$ at $37^{\circ} \mathrm{C}$, and cell viability was determined using a Cell Counting Kit-8 (CCK-8) assay. CCK-8 reagent (Dojindo Molecular Technologies, Inc.) was incubated with the cells at $37^{\circ} \mathrm{C}$ for $3 \mathrm{~h}$. Then, the MCF7/Adr cells were treated with $\operatorname{Adr}\left(\mathrm{IC}_{50} 2.28 \mu \mathrm{M}\right)$ or Doc $\left(\mathrm{IC}_{50} 1.63 \mu \mathrm{M}\right)$ at different time points, and cell viability was measured after $24,48,72,96$ and $120 \mathrm{~h}$ of treatment.

Cell transfection. miR-125a-5p mimics (5'-AGUGUU CAAUCCCAGAGUCCCU-3') and NC (5'-CUCAUU CCCAUAUGGUCGCAAG-3') mimics were synthesized by Shanghai GenePharma Co., Ltd. Small interfering (si)RNA-TAFAZZIN (5'-GGAUACAGGAGAAAACGCA-3') and si-TAFAZZIN-NC (siRNA NC) were obtained from Qiagen, Inc., to regulate the expression of TAFAZZIN. In accordance with the manufacturer's instructions, breast cancer cells were seeded into 96 -well plates $\left(4 \times 10^{4}\right.$ cells/well). The cells were transfected using Lipofectamine ${ }^{\circledR} 2000$ (Invitrogen; Thermo Fisher Scientific, Inc.) at room temperature for $10 \mathrm{~min}$. The complexes were added dropwise on the cells and the plates were incubated at $37^{\circ} \mathrm{C}$ in $5 \% \mathrm{CO}_{2}$. Following treatment of the breast cancer cells with miR-125a-5p for 6 days, the cells were then observed, and all images were captured on a Leica DM1 confocal microscope (magnification, x200; Leica Microsystems, Inc.).

Reverse transcription-quantitative (RT-q)PCR. Total RNA from cultured cells and tissues was isolated using TRIzol ${ }^{\circledR}$ reagent (Sigma-Aldrich; Merck KGaA) following the manufacturer's protocol. RNA quality and quantity were quantified using a Nano-drop 2000 spectrophotometer (Thermo Fisher Scientific, Inc.). Next, $2 \mu \mathrm{g}$ total RNA was reverse transcribed into cDNA using PrimeScript RT Master mix (Takara Bio, Inc.) at $37^{\circ} \mathrm{C}$ for $1 \mathrm{~h}$. qPCR was performed under the following thermocycling conditions: $30 \mathrm{~min}$ at $50^{\circ} \mathrm{C}$ followed by $10 \mathrm{~min}$ at $95^{\circ} \mathrm{C} ; 40$ cycles of $60^{\circ} \mathrm{C}$ for $1 \mathrm{~min}$ followed by $95^{\circ} \mathrm{C}$ for 15 sec. qPCR was performed using a SYBR Green qPCR Master Mix kit (Takara Bio, Inc.) with gene-specific primers. GAPDH and U6 served as internal references for mRNA and miRNA, respectively. The sequences for the PCR primers are as follows: TAFAZZIN forward (FW), 5'-ACACCCTGCAAT CTTTCAGACA-3' and reverse (RV), 5'-GATTCCACTTTG CGT-3'; miR-125a-5p FW, 5'-CTGGAAACAGAGGGATGC-3' and RV, 5'-CCTGGCTCCTCACTTGGC-3'; GAPDH FW, 5'-AAGTACTCCGTGTGGATCGG-3' and RV, 5'-ATGCTA TCACCTCCCCTGTG-3'; and U6 FW, 5'-CTCGCTTCGGCA GCACA-3' and RV, 5'-AACGCTTCACGAATTTGCGT-3'. Differences in gene expression were calculated using the $2^{-\Delta \Delta C q}$ method (18).

Western blotting examination. The cultured cells were washed and harvested in a lysis solution. Whole cell lysates were prepared using RIPA buffer (Sigma-Aldrich; Merck KGaA) containing a protease cocktail inhibitor (Thermo Fisher Scientific, Inc.), with quantification using the Pierce ${ }^{\text {TM }}$ BCA Protein assay kit (Thermo Fisher Scientific, Inc.). The proteins were separated by SDS-PAGE on $10 \%$ acrylamide gels, and subsequently transferred to PVDF membranes by electroblotting. Membranes were blocked with $2.5 \%$ non-fat milk at room temperature for $2 \mathrm{~h}$ and washed in TBS containing $0.1 \%$ Tween-20. Membranes were incubated with primary antibodies $(1: 1,000)$ for $12-18 \mathrm{~h}$ at $4^{\circ} \mathrm{C}$, and then incubated for $1 \mathrm{~h}$ in HRP-conjugated secondary antibodies (1:1,000; cat. nos. SA00001-1 and SA00001-2; ProteinTech Group, Inc.) at room temperature. The membranes were 
probed using the following antibodies: Anti-TAFAZZIN (cat. no. 703032; Invitrogen; Thermo Fisher Scientific, Inc.), anti-TG2 (cat. no. ab109200; Abcam), anti-E-cadherin (cat. no. ab40772; Abcam), anti-N-cadherin (cat. no. ab18203; Abcam), anti-vimentin (cat. no. ab217673; Abcam), anti-GAPDH (cat. no. ab8245; Abcam), anti-cleaved caspase-3 (cat. no. 9661; Cell Signaling Technology, Inc.), anti-caspase-3 (cat. no. 9662; Cell Signaling Technology, Inc.), anti-phosphorylated (p)-AKT (cat. no. 4060; Cell Signaling Technology, Inc.), anti-total (t)-AKT (cat. no. 4691; Cell Signaling Technology, Inc.), anti- $\beta$-catenin (cat. no. MA1-301; Invitrogen; Thermo Fisher Scientific, Inc.), anti-proliferating cell nuclear antigen (PCNA; cat. no. 13-3900; Invitrogen; Thermo Fisher Scientific, Inc.), anti-Bcl-2 (cat. no. 13-8800; Invitrogen; Thermo Fisher Scientific, Inc.) and anti-Bax (cat. no. ab32503; Abcam). The blots were reprobed with an antibody against GAPDH as the loading control. The membrane was exposed to an ECL solution (Beijing Solarbio Science \& Technology Co., Ltd.) and imaged with a Bio-Rad Versa Doc Imaging System (Bio-Rad Laboratories, Inc.). Finally, the protein bands were analyzed by Image Lab software (version 6.0; Bio-Rad Laboratories, Inc.).

Cell proliferation assay. Cell proliferation was analyzed using a Cell Counting Kit-8 (CCK-8; Dojindo Molecular Technologies, Inc.), in accordance with the manufacturer's protocols. The cells were harvested via trypsin digestion and passed through No. 400 stainless steel meshes, following which they were uniformly added into 96-well plates at a concentration of $3 \times 10^{3}$ cells/well. When the cells grew to a confluence of $60 \%$, they were divided into groups according to treatment and incubated at $37^{\circ} \mathrm{C}$ for $72 \mathrm{~h}$. CCK-8 reagent ( $10 \mu \mathrm{l} /$ well) was added to culture medium and incubated with the cells at $37^{\circ} \mathrm{C}$ for an additional $3 \mathrm{~h}$. Absorbance was measured at $450 \mathrm{~nm}$ using a microplate reader (Molecular Devices, LLC), with the optical density (OD) values of each well representing the survival/proliferation of cells. The proliferation inhibition rates $(\%)=($ the average OD value in all duplicates in control group-the average OD value in medicine groups)/the average OD value in blank control group x $100 \%$. These experiments were repeated independently $\geq 3$ times.

Cell apoptosis assay. Flow cytometry analysis was determined using the annexin V/PI method (annexin V-FITC/PI apoptosis kit; BestBio) in accordance with the manufacturer's protocols. The cells were seeded into $25-\mathrm{ml}$ flasks and divided into groups according to treatment. After $48 \mathrm{~h}$, the cells were washed, harvested, resuspended in $100 \mu 1 \mathrm{X}$ binding buffer and stained with $5 \mu \mathrm{l}$ FITC-annexin V and $5 \mu \mathrm{l}$ PI for $15 \mathrm{~min}$ at room temperature in the dark. The samples were analyzed via flow cytometry (Excitation=488 nm; Emission=530 nm). The percentage distributions of normal, early apoptotic, late apoptotic and necrotic cells were calculated using ModFitLT v3.0 software (BD Biosciences) and the results were calculated from three independent experiments.

Dual-luciferase reporter assay. Bioinformatics analysis was conducted using TargetScan Human Release 7.2 (http://www.targetscan.org/vert_72/). The sequence of target genes 3'-untranslated region (UTR) was cloned and inserted into the psiCHECK2 vector encoding dual-luciferase (Promega Corporation). For luciferase assay, MCF-7/Adr cells were co-transfected with miR-125a-5p mimic or control miRNA mimics and luciferase vector containing the full-length 3 '-UTR of TAFAZZIN using Lipofectamine ${ }^{\circledR} 2000$ (Invitrogen; Thermo Fisher Scientific, Inc.). At $24 \mathrm{~h}$ post co-transfection, the cells were harvested, lysed and analyzed with the dual-luciferase assay kit (Promega Corporation), according to the manufacturer's protocol, to determine the firefly and Renilla luciferase activity. The firefly luciferase activity was normalized according to the Renilla activity. Relative light units were examined, and the experiments were performed in triplicate.

RNA immunoprecipitation (RIP) assay. An Immunoprecipitation kit (cat. no. ab206996; Abcam) was used to perform the RIP assay, in accordance with the manufacturer's protocols. MCF-7/Adr cells were treated with formaldehyde to cross-link in vivo Protein-RNA complexes, and harvested by trypsinization and resuspended in PBS, freshly prepared nuclear isolation buffer and water on ice for $20 \mathrm{~min}$ (with frequent mixing). Nuclei were pelleted by centrifugation at $2,500 \mathrm{x} \mathrm{g}$ at $4^{\circ} \mathrm{C}$ for $15 \mathrm{~min}$. The nuclear pellet was resuspended in freshly prepared RIP buffer $(1 \mathrm{ml})$. Resuspended nuclei were split into two fractions of $500 \mathrm{ml}$ each (for mock and IP) and were mechanically sheared using a Dounce homogenizer with 15-20 strokes. Nuclear membrane and debris were pelleted by centrifugation at $6,500 \mathrm{x} g$ at $4^{\circ} \mathrm{C}$ for $10 \mathrm{~min}$. Antibody to TAFAZZIN (10 $\mu \mathrm{g}$; cat. no. 703032; Invitrogen; Thermo Fisher Scientific, Inc.) was added to the supernatant $\left(10 \mathrm{mg}\right.$ ) and incubated for $2 \mathrm{~h}$ (to overnight) at $4^{\circ} \mathrm{C}$ with gentle shaking. Protein A/G beads $(40 \mu \mathrm{l})$ were added and incubated for $1 \mathrm{~h}$ at $4^{\circ} \mathrm{C}$ with gentle shaking. Beads were pelleted at $1,250 \mathrm{x} \mathrm{g}$ at $4^{\circ} \mathrm{C}$ for $30 \mathrm{sec}$, the supernatant was removed and beads were resuspended in $500 \mathrm{ml}$ RIP buffer. This was repeated for a total of three RIP washes, followed by one wash in PBS. Beads were resuspended in TRIzol RNA extraction reagent $(1 \mathrm{ml})$. Co-precipitated RNAs were isolated and Protein isolated by the beads was detected via western blotting, while RNA was detected via RT-qPCR.

Tissue samples. Tumor samples were collected from 45 patients with newly diagnosed locally advanced breast cancer female aged 45-60 years, who received four cycles of Adr and cyclophosphamide, followed by four cycles of Doc $(\mathrm{AC} \rightarrow \mathrm{T})$ neoadjuvant therapy for early breast cancer in Jiangxi Provincial Cancer Hospital (Nanchang, China) between January 2018 and December 2020. Exclusion criteria included patients who had received radiotherapy or chemotherapy. Written informed consent was obtained from all participants prior to experiments, which were conducted after agreement from the Ethics Committee of Jiangxi Provincial Cancer Hospital (approval no. 20180314).

The samples were immediately placed in $-80^{\circ} \mathrm{C}$ refrigerators until RNA extraction. At room temperature specimens were fixed in $10 \%$ formalin for $10 \mathrm{~h}$. The tissues were cut into 4- $\mu \mathrm{m}$ thick slices and stained with hematoxylin and eosin (H\&E) at $20^{\circ} \mathrm{C}$ for $2 \mathrm{~h}$, and imaged using a Leica DM1 confocal microscope (Leica Microsystems, Inc.). Using H\&E-stained breast tissue, pathologic responses to chemotherapy were 
A

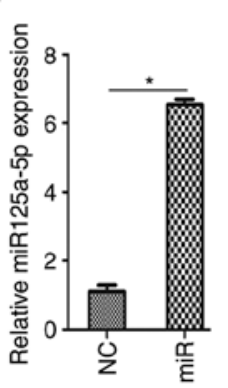

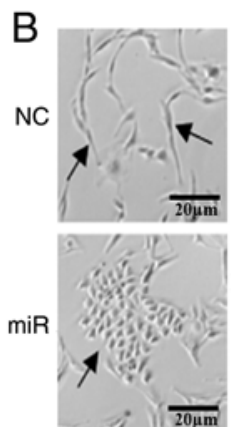

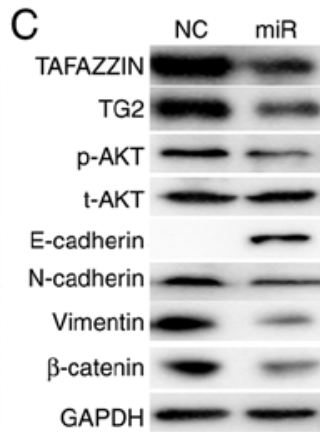

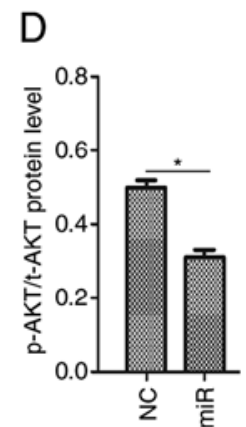

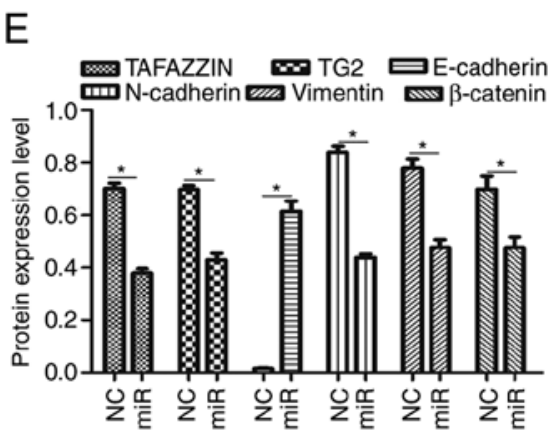

Figure 1.miR-125a-5p reverses epithelial-mesenchymal transition in MCF7/Adr cells. (A) Transfection efficiency of mimics was determined via reverse transcription-quantitative PCR. miR-125a-5p was overexpressed after transfection of mimics in MCF-7/Adr cells. (B) Cell morphological alterations after miR-125a-5p transfection, as indicated by arrows. Images of cells in medium. The cells of NC groups remained elongated and dispersed with a mesenchymal morphology, and the cells of miR-125a-5p groups were closely packed and rounded with a cobblestone epithelial morphology; magnification, $\mathrm{x} 200$ ( $\mathrm{scale}$ bar, $20 \mu \mathrm{m}$ ). (C) Western blot analysis of TAFAZZIN, TG2, AKT, E-cadherin, N-cadherin, vimentin and $\beta$-catenin in MCF7/Adr cells. (D and E) Semi-quantification of protein expression results from panel (C). GAPDH served as an internal control. Data are presented as the mean \pm SD. Similar results were obtained from three independent experiments. ${ }^{*} \mathrm{P}<0.05$, as obtained via unpaired Student's t-test. TAFAZZIN, tafazzin phospholipid-lysophospholipid transacylases; miR, microRNA; p-, phosphorylated; t-, total; TG2, Transglutaminase 2; Adr, Adriamycin; NC, negative control.

independently evaluated by two pathologists following the Miller and Payne (MP) grading system (19): Grade 1, no change in tumor lesions; Grade 2, a small number of tumor cells disappeared $(<30 \%)$; Grade 3 , most of the tumor tissues (30-90\%) disappeared; Grade 4, marked (>90\%) disappearance of tumor cells; and Grade 5, no residual invasive carcinoma. Grade 3 to 5 cancer types were defined as chemosensitive group, and grade 1 and 2 tumors were classified into chemoresistant group (20). In total, 45 pre-chemotherapy biopsy samples from chemosensitive $(n=25)$ and chemoresistant cases $(n=20)$ were selected for the detection of miR-125a-5p and TAFAZZIN expression using RT-qPCR.

Statistical analysis. Statistical analysis was performed using SPSS 17.0 software (SPSS, Inc.). Data are presented as the mean \pm SD from at least three independent experiments. Unpaired Student's t-test and one-way ANOVA followed by post hoc Tukey's test were used to compare the data from different groups. Pearson's correlation was applied to examine the correlations between variables. $\mathrm{P}<0.05$ was considered to indicate a statistically significant difference.

\section{Results}

miR-125a-5p reverses EMT in MCF7/Adr cells. The transfection efficiency was evaluated via RT-qPCR. After transfection with mimics, the expression level of miR-125a-5p in MCF7/Adr cells was significantly increased (Fig. 1A). MCF7/Adr cell lines showed changes in morphology 6 days after miR-125a-5p treatment. Under a Leica DM1 confocal microscope, the cells of NC groups remained elongated and dispersed with a mesenchymal morphology, whereas the cells of miR-125a-5p groups were closely packed and rounded with a cobblestone epithelial morphology (Fig. 1B). These data suggested that miR-125a-5p may be associated with an epithelial morphology.

For further confirmation, the expression levels of typical epithelial and mesenchymal markers were examined. Western blot analysis (Fig. 1C-E) demonstrated that after the breast cancer cells were treated with miR-125a-5p for 6 days, several
EMT-related transcriptional factors, including TG2, p-AKT, $\mathrm{N}$-cadherin, vimentin and $\beta$-catenin, were downregulated, while E-cadherin (an adherens junction marker) expression was significantly increased compared with the NC group. The EMT marker analysis indicated that miR-125a-5p induced the epithelial program and possibly inhibited the EMT of breast cancer.

miR-125a-5p decreases the proliferation of MCF7/Adr breast cancer cells treated with Adr or Doc. The involvement of miR-125a-5p in the regulation of Adr/Doc resistance in MCF7/Adr cells was determined by examining the effect of these drugs on chemosensitivity. MCF7/Adr cells were initially treated with different concentrations of Adr or Doc and miR-125a-5p for $72 \mathrm{~h}$, and cell viability was then determined. CCK-8 assay results identified that Adr or Doc inhibited breast cancer cell proliferation in a concentration-dependent manner, and miR-125a-5p enhanced this effect. After miR-125a-5p treatment, the $\mathrm{IC}_{50}$ was reduced from 5.99 to $2.28 \mu \mathrm{M}$ in the MCF-7/Adr cells treated with Adr, and from 5.01 to $1.63 \mu \mathrm{M}$ in the cells treated with Doc (Fig. 2A and B).

The MCF7/Adr cells were then treated with $\operatorname{Adr}(2.28 \mu \mathrm{M})$ or Doc $(1.63 \mu \mathrm{M})$ at different time points, and cell viability was measured after 5 days of treatment (Fig. 2C and D). The viability of cells transfected with miR-125a-5p was lower compared with that of control cells following Adr/Doc treatment, suggesting that miR-125a-5p resensitizes these cells to Adr/Doc. Therefore, the combination of Adr or Doc and miR-125a-5p has a synergistic antitumor effect, and miR-125a-5p promotes Adr or Doc sensitivity in MCF7/Adr breast cancer cells.

It was found that combination of miR-125a-5p and Adr or Doc significantly inhibited the proliferation of MCF7/Adr cells compared with the control groups. Moreover, a decrease in PCNA expression was observed in the combined treatment group (Fig. 2I, J, L and N).

miR-125a-5p promotes the apoptosis of MCF7/Adr cells treated with Adr or Doc. The apoptotic rates in MCF-7/Adr cells treated with Adr or Doc for $48 \mathrm{~h}$ were assessed to further analyze 
A

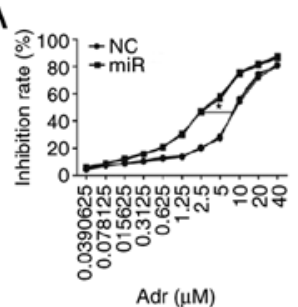

B

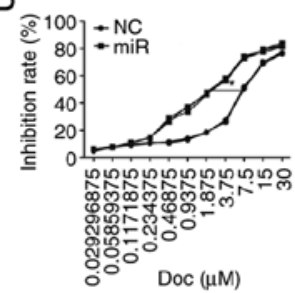

C

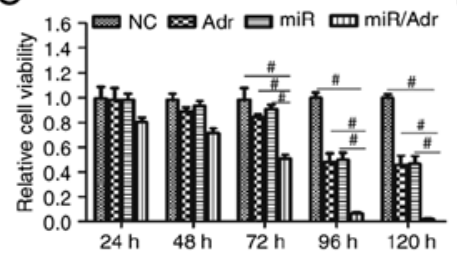

D

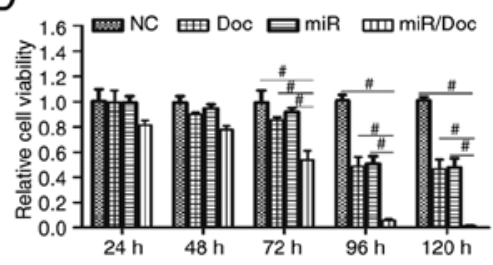

E a

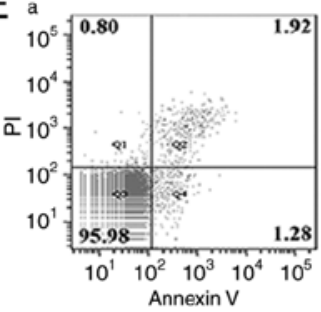

F

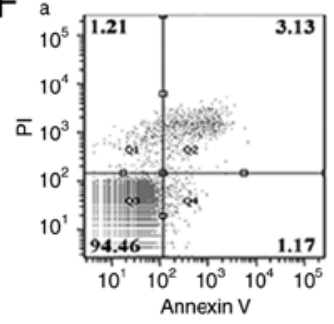

G
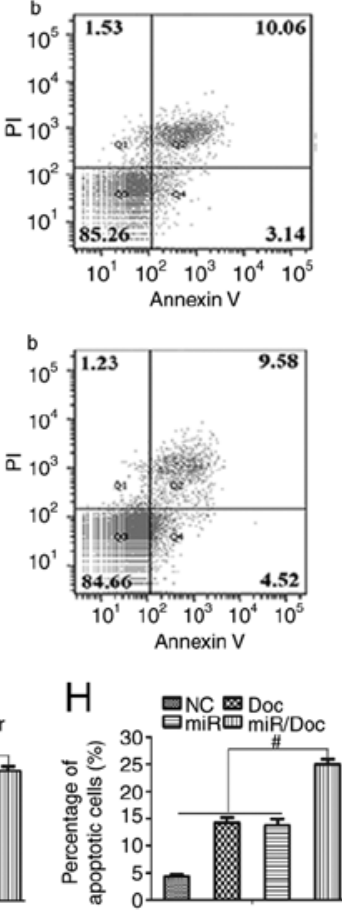
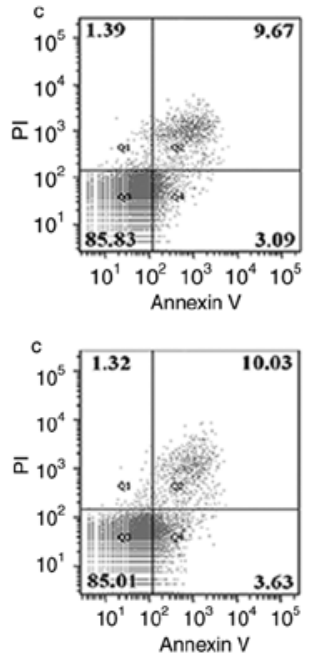
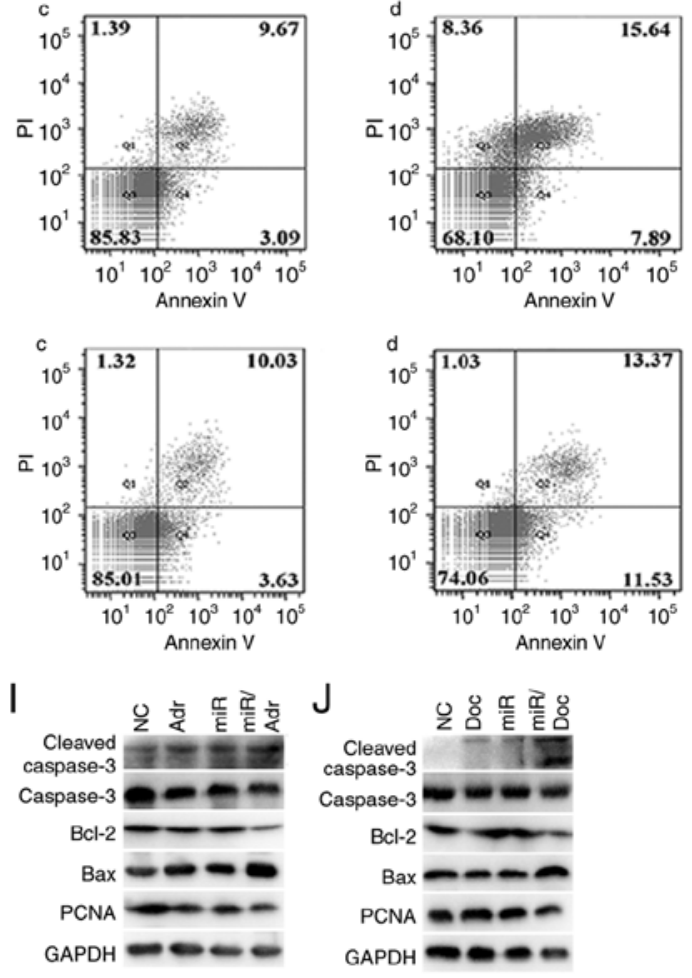

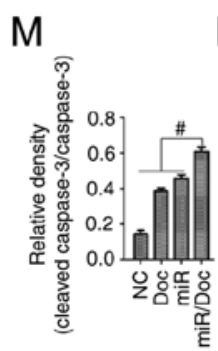

N

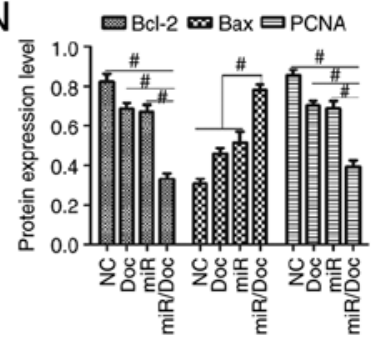

Figure 2. miR-125a-5p inhibits proliferation and promotes apoptosis via tafazzin phospholipid-lysophospholipid transacylases signaling. Cellular inhibition rates were determined using CCK-8 assays. MCF-7/Adr cells were treated with various concentrations of Adr or Doc for $72 \mathrm{~h}$. Inhibitory effects were increased with miR-125a-5p transfection. The $\mathrm{IC}_{50}$ was reduced from $5.99 \mu \mathrm{M}(\mathrm{NC})$ to $2.28 \mu \mathrm{M}(\mathrm{miR})$ in the MCF-7/Adr cells (A) treated with Adr, and from 5.01 $\mu \mathrm{M}(\mathrm{NC})$ to $1.63 \mu \mathrm{M}(\mathrm{miR})$ in the cells (B) treated with Doc. MCF-7/Adr cells were transfected with miR-125a-5p and treated with (C) Adr (2.28 $\mu \mathrm{M})$ or (D) Doc $(1.63 \mu \mathrm{M})$ for $24,48,72,96$ and $120 \mathrm{~h}$. The CCK-8 assay results indicated that this combination inhibited MCF-7/Adr cell viability. (E and G) Apoptotic rate of MCF-7/Adr breast cancer cells treated with Adr, as detected via flow cytometry. (F and H) Apoptotic rate of MCF-7/Adr breast cancer cells treated with Doc as detected via flow cytometry. a, NC group; b, drug group; c, miR (miR-125a-5p) group; d, miR/drug group. Caspase-3 activation and increased Bax expression were observed in MCF7/Adr cells transfected with miR-125a-5p and treated with (I) Adr or (J) Doc; the combination of miR-125a-5p and Adr or Doc kept Bcl-2 and PCNA expression at the lowest level, as determined via western blot analysis. GAPDH served as an internal control. (K and L) Semi-quantification of protein expression levels in panel (I). (M and N) Semi-quantification of protein expression levels in panel (J). Data are shown as the mean \pm SD. Similar results were obtained from three independent experiments. ${ }^{*} \mathrm{P}<0.05$, as obtained via unpaired Student's t-test; ${ }^{\#} \mathrm{P}<0.05$, as obtained via one-way ANOVA with Tukey's post hoc test. miR, microRNA; CCK-8, Cell Counting Kit-8; Adr, Adriamycin; NC, negative control; Doc, docetaxel; PCNA, proliferating cell nuclear antigen.

how miR-125a-5p affects Adr or Doc resistance. With miR-125a-5p transfection, the apoptotic rates were increased from 13.2 to $23.5 \%$ in the MCF-7/Adr cells treated with Adr, and from 14.1 to $24.9 \%$ in the cells with treated with Doc. Annexin-V binding results revealed that, compared with that in the MCF-7/Adr cells, the number of apoptotic tumor cells was significantly increased in miR/Adr and miR/Doc groups. This finding suggested that miR-125a-5p transfection enhanced the apoptosis and improved the anti-cancer effect of Adr/Doc (Fig. 2E-H).

Annexin-V staining identified that the combination of miR-125a-5p and Adr or Doc significantly promoted the 
apoptosis of MCF7/Adr cells compared with each individual treatment. Caspase-3 activation, anti-apoptotic protein $\mathrm{Bcl}-2$ downregulation and increased pro-apoptotic Bax protein expression were observed in the combined treatment group (Fig. 2I-N). Therefore, it was suggested that miR-125a-5p resensitized MCF7/Adr cells to Adr and largely elevated the efficacy of Doc.

miR-125a-5p downregulates TAFAZZIN expression in $M C F 7 / A d r$ cells. Although TAFAZZIN is reportedly regulated by miR-125a-5p $(13,14)$, there is currently not sufficient evidence to determine the relationship between TAFAZZIN and miR-125a-5p in breast cancer. Hence, bioinformatics analysis was conducted and the results demonstrated that TAFAZZIN contains a putative binding site for miR-125a-5p (Fig. 3A) and, thus, is a potential target of this gene. TAFAZZIN 3'-UTR sequences were then introduced into psiCHECK2 luciferase reporter vectors and co-transfected with miR-125a-5p mimics into MCF7/Adr cells. Dual-luciferase and RIP assays were performed to identify the association between miR-125a-5p and TAFAZZIN (Fig. 3A-F). The results indicated that TAFAZZIN could be negatively controlled by miR-125a-5p. As shown in Fig. 3D-F, TAFAZZIN mRNA and protein expression was decreased in the miR-125a-5p group compared with the control groups.

The luciferase activity was decreased in cells transfected with mimic and wild-type TAFAZZIN. However, this phenomenon was not observed in the control group transfected with mutant (Fig. 3B). A RIP assay was used to verify this relationship. RT-qPCR analysis revealed that TAFAZZIN and miR-125a-5p were enriched in Ago2-binding beads compared with those in the input group (Fig. 3C), indicating that miR-125a-5p may directly bind to the target sites of TAFAZZIN 3'-UTR. Hence, TAFAZZIN is a direct binding target of miR-125a-5p, and a possible interplay exists between these two factors.

SiRNA-TAFAZZIN induces changes in the expression levels of EMT- and drug resistance-related proteins. TAFAZZIN expression in MCF7/Adr cells was decreased after transfection with siRNA-TAFAZZIN to further analyze the function and signal pathway of the miR-125a-5p target gene in the EMT and drug resistance of breast carcinoma. The expression levels of TG2, p-AKT, t-AKT, epithelial protein (E-cadherin), mesenchymal markers (N-cadherin, vimentin and $\beta$-catenin), pro-apoptotic protein (Bax) and proliferation marker (PCNA) were examined in MCF7/Adr cells. Western blot analysis (Fig. 3G-L) revealed that TAFAZZIN knockdown activated caspase-3, increased Bax and E-cadherin expression and downregulated TAFAZZIN, TG2, p-AKT, N-cadherin, vimentin and PCNA expression compared with the NC group. These data suggested that TAFAZZIN knockdown may inhibit the EMT and drug resistance of MCF7/Adr cells. In addition, TAFAZZIN was reversely modulated by miR-125a-5p, and the miR-125a-5p/TAFAZZIN axis may play an important role in modulating the EMT of MCF-7/Adr breast cancer. All these data indicated that miR-125a-5p and TAFAZZIN are associated with the likelihood of drug resistance.
miR-125a-5p and TAFAZZIN expression in relation to the neoadjuvant chemotherapy response. miR-125a-5p and TAFAZZIN mRNA expression in clinical breast tumor tissues was detected to determine the clinical importance of miR-125a-5p and TAFAZZIN in chemotherapy-resistant breast tumors. According to the MP grading system, 25 chemosensitive cases and 20 chemoresistant cases who received neoadjuvant chemotherapy were selected (Fig. 4A) (14). RT-qPCR was used to detect miR-125a-5p and TAFAZZIN expression in the pre-chemotherapy biopsy samples from patients with breast cancer who received four cycles of Adr and cyclophosphamide, followed by four cycles of Doc $(\mathrm{AC} \rightarrow \mathrm{T})$ neoadjuvant therapy. Increased miR-125a-5p expression was found in the breast tumors from patients who achieved chemotherapy response (chemosensitive group; Fig. 4B), while TAFAZZIN mRNA expression was increased in the chemoresistant group (Fig. 4C). This finding indicated a close relationship between miR-125a-5p/TAFAZZIN expression and chemotherapy response. Pearson's correlation analysis also indicated that the expression level of miR-125a-5p was negatively correlated with TAFAZZIN mRNA expression in breast cancer tissues (Fig. 4D).

\section{Discussion}

Drug-resistant cancer cells display features of EMT; hence, the reversal of breast cancer cell EMT could inhibit cancer drug resistance (21). In the present study, it was identified that miR-125a-5p induced MCF-7/Adr cells to undergo partial morphological alternation from fibroblast-like to round cobblestone-like cells, resulting in the upregulation of epithelial markers and the downregulation of mesenchymal markers. The expression levels of E-cadherin, $\mathrm{N}$-cadherin, vimentin and $\beta$-catenin were used as markers of epithelial and mesenchymal phenotypes. The regulatory role of miR-125a-5p for EMT and its effect on the expression levels of EMT markers were analyzed. The results demonstrated that TAFAZZIN, TG2, N-cadherin, vimentin and $\beta$-catenin expression levels were significantly lower in MCF-7/Adr cells transfected with miR-125a-5p compared with those in the NC groups. These results suggested that miR-125a-5p decreased the expression levels of TAFAZZIN, TG2, AKT, N-cadherin, vimentin and $\beta$-catenin, and consequently reverses EMT.

The role of miR-125a-5p in Adr and Doc resistance in breast cancer was further examined. The miR-125a-5p transfection group exhibited suppressed proliferation, and all the miR-125a-5p transfection groups showed enhanced apoptotic rates compared with the control groups. In breast cancer cells, miR-125a-5p inhibited cancer growth by inhibiting proliferation and inducing apoptosis. In breast cancer, miR-125a-5p suppressed cell proliferation and enhanced the anti-cancer effect of Adr or Doc. Moreover, miR-125a-5p contributed to an increased sensitivity to the drugs. Tumor samples were collected from patients who received the sequential administration of Adr and Doc in neoadjuvant therapy for early breast cancer to investigate the relationship between miR-125a-5p/TAFAZZIN and the antitumor effect of Adr or Doc in vivo. Increased miR-125a-5p expression was found in the breast tumors from patients who achieved chemotherapy response, and the mRNA expression level of 
A

hsa-miR-125a-5p

Position 421-428 of TAFAZZIN 3' UTR (wild type)

TAFAZZIN 3' UTR (mutant)

\section{3' AGUGUCCAAUUUCCCAGAGUCCCU-5 \\ 5' AGCUGCUCACUACCUCCUCAGGGA-3' \\ 5' AGCUGCUCACUACCUCCUGUCCCA-3'}

B

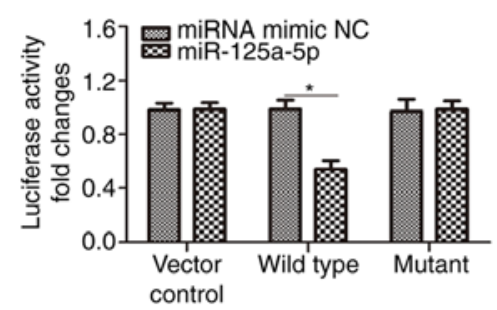

E

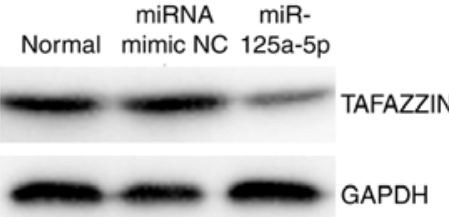

G
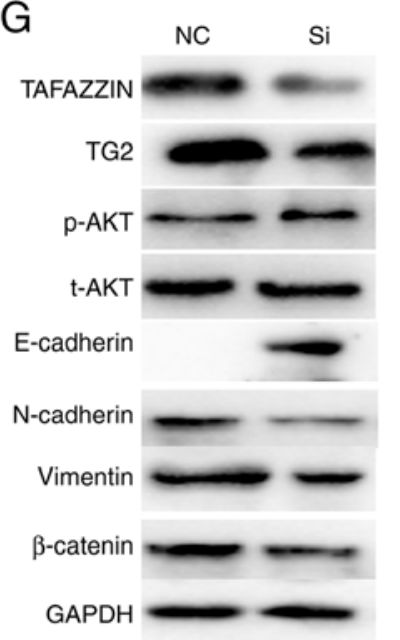

$\mathrm{H}$

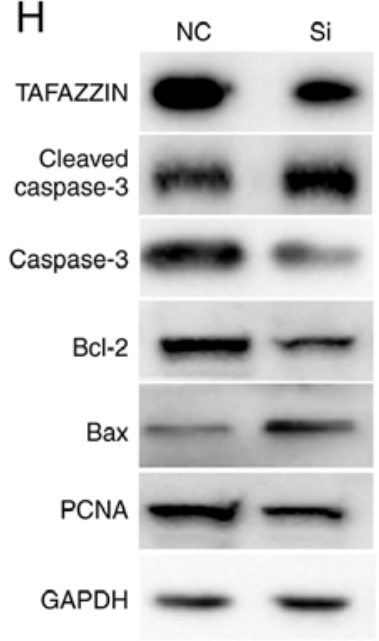

C

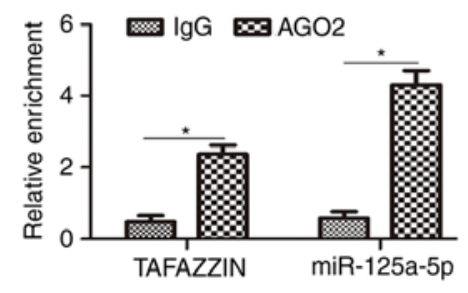

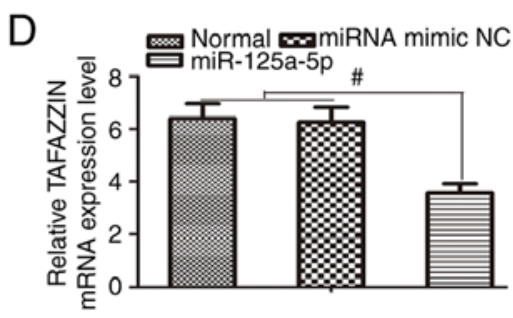

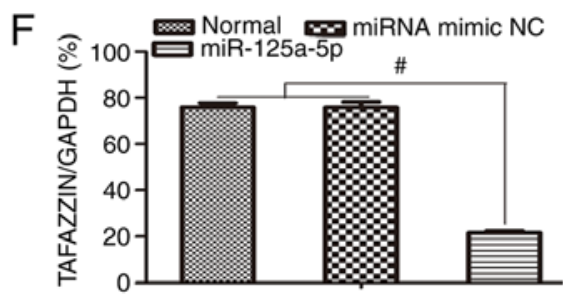

I

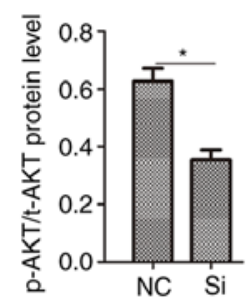

$\mathrm{K}$

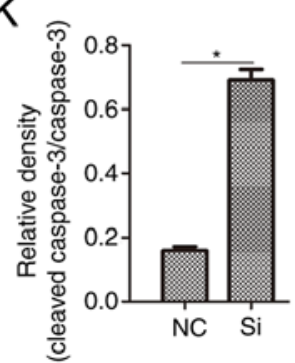

J
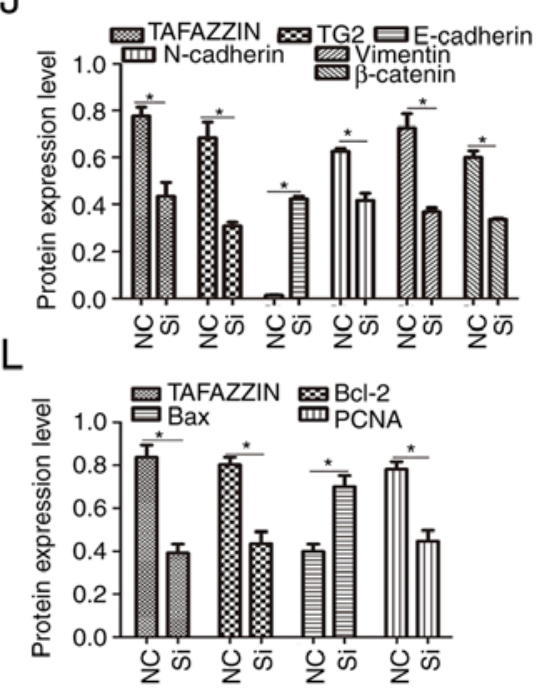

Figure 3. TAFAZZIN is a target of miR-125a-5p in MCF-7/Adr cells. (A) Binding site of miR-125a-5p and TAFAZZIN 3'-UTR according to online bioinformatics analysis. (B) Luciferase activity was decreased for wild-type-TAFAZZIN, but not for the mutant. (C) RNA immunoprecipitation assay indicated that miR-125a-5p and TAFAZZIN were conjunct in MCF-7/Adr cell lines. (D) TAFAZZIN mRNA expression in miR-125a-5p and control groups as detected via reverse transcription-quantitative PCR. (E) Western blot analysis of TAFAZZIN protein expression in miR-125a-5p and control groups. (F) Semi-quantification of TAFAZZIN protein expression in panel (E). MCF-7/Adr cells were treated with siRNA-TAFAZZIN, and the expression levels of (G) TAFAZZIN, TG2, p-AKT, t-AKT, E-cadherin, N-cadherin, vimentin, $\beta$-catenin, (H) cleaved caspase-3, caspase-3, pro-apoptotic protein (Bax) and PCNA were detected via western blotting. Knockdown of TAFAZZIN expression could significantly reduce TAFAZZIN, TG2, p-AKT, N-cadherin, vimentin, $\beta$-catenin, Bcl-2 and PCNA protein expression and increase those of E-cadherin and Bax, as well as activate caspase-3. (I-L) Semi-quantification of protein levels in panels $(\mathrm{G}$ and $\mathrm{H})$. GAPDH was used as an internal reference. Data are shown as the mean \pm SD. Similar results were obtained from three independent experiments. "P<0.05, as obtained via unpaired Student's t-test; ${ }^{*} \mathrm{P}<0.05$, as obtained via one-way ANOVA with Tukey's post hoc test. TAFAZZIN, tafazzin phospholipid-lysophospholipid transacylases; miR, microRNA; p-, phosphorylated; t-, total; TG2, Transglutaminase 2; Adr, Adriamycin; NC, negative control; UTR, untranslated region; siRNA/si, small interfering RNA; PCNA, proliferating cell nuclear antigen.

TAFAZZIN was upregulated in the patients who achieved no-chemotherapy response. Hence, a close relationship was observed between miR-125a-5p/TAFAZZIN expression and chemotherapy response (Fig. 4E). These data suggested that miR-125a-5p/TAFAZZIN was significantly associated with the antitumor effect of Adr and Doc in patients with breast cancer.
TG2 downregulation can reverse EMT and modulate the chemosensitivity of MDA-MB-231 triple-negative breast cancer cells (15). The present study demonstrated that miR-125a-5p downregulated TG2 expression, leading to the changes associated with EMT and the increase in the sensitivity of MCF-7/Adr cells. This finding was consistent with our previous study (15). Furthermore, TG2 suppresses 
A
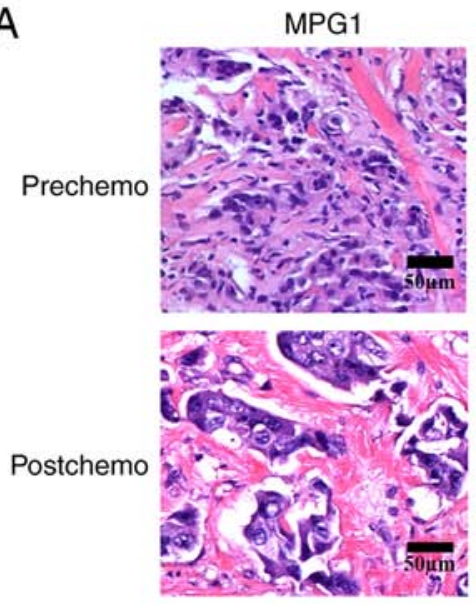

B

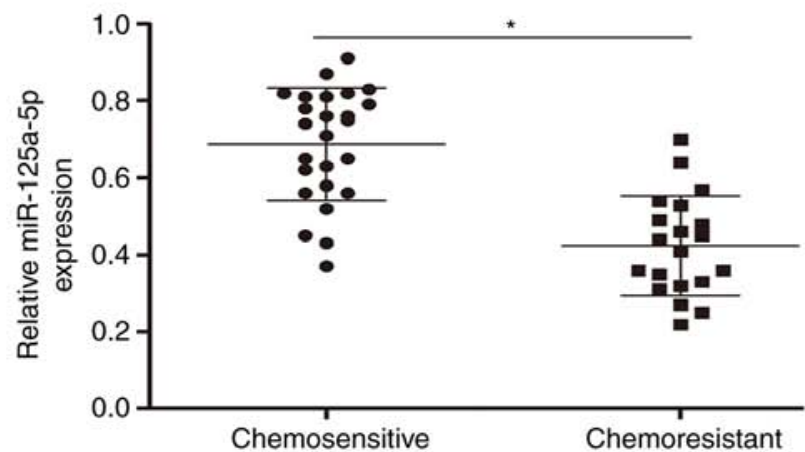

D

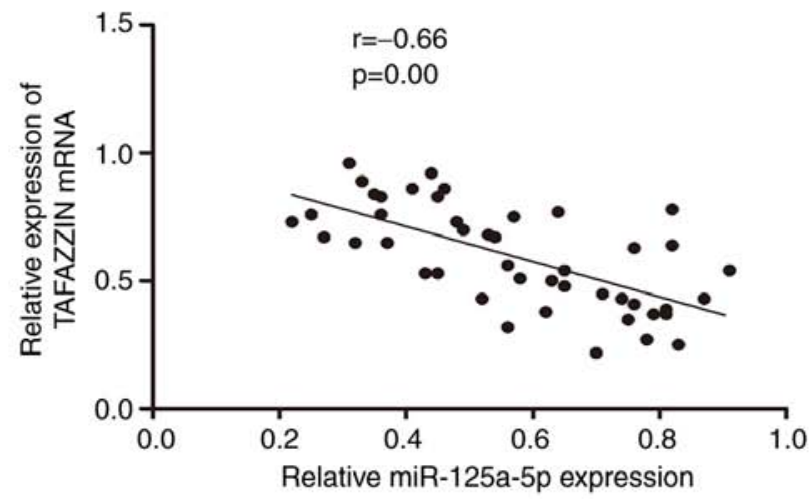

MPG2
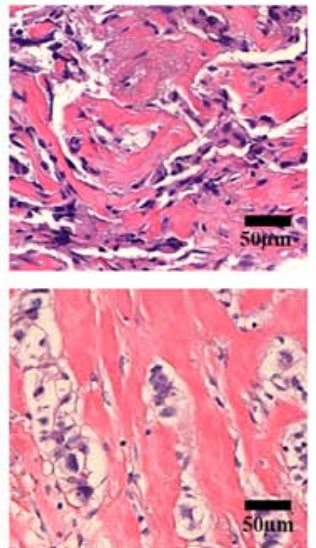

MPG4
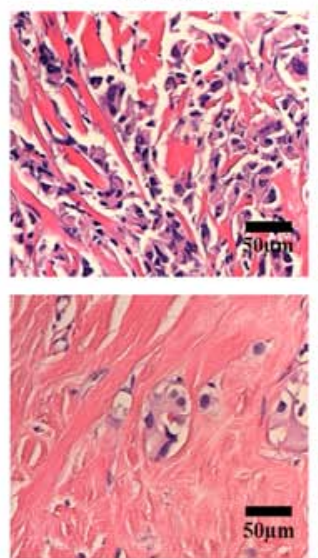

C

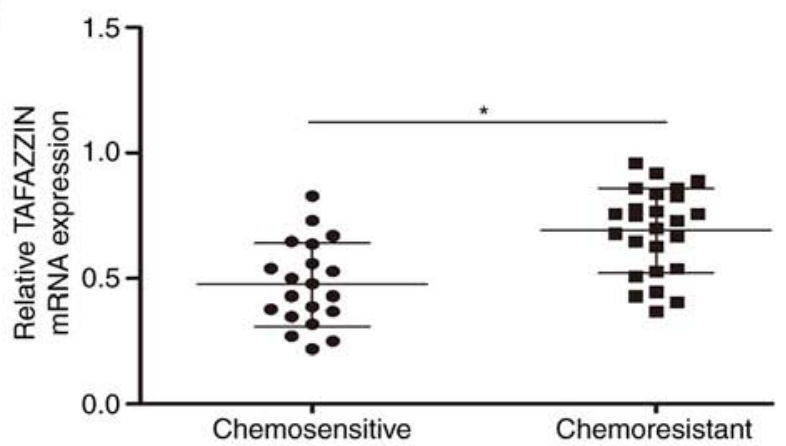

E

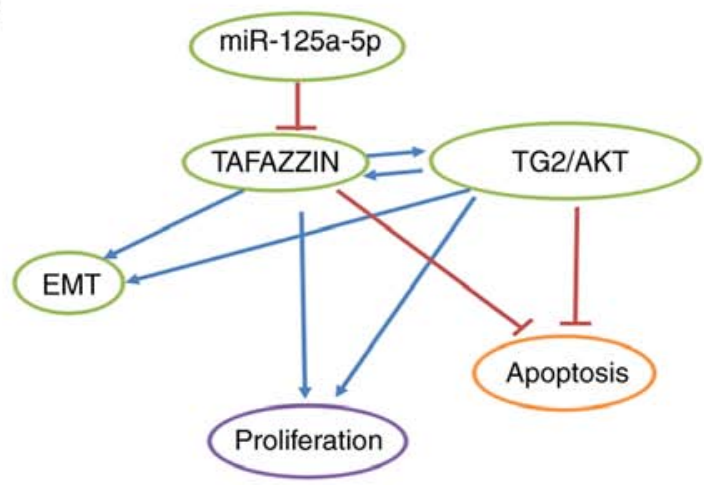

Figure 4. miR-125a-5p increases drug sensitivity via TAFAZZIN signaling in breast cancer. (A) Morphological changes in breast cancer specimens (magnification, x200; scale bar, $50 \mu \mathrm{m}$; hematoxylin and eosin). Prechemo, before neoadjuvant chemotherapy; Postchemo, after neoadjuvant chemotherapy. Different mRNA expression levels of (B) miR-125a-5p and (C) TAFAZZIN in pre-chemotherapy biopsy samples (45 pre-chemotherapy biopsy samples from 25 chemosensitive cases and from 20 chemoresistant cases). Compared with that in chemoresistant group, the expression level of miR-125a-5p was elevated in chemosensitive group. Compared with that in chemosensitive group, TAFAZZIN mRNA expression was increased in the chemoresistant group. (D) Pearson's correlation analysis revealed that miR-125a-5 expression was negatively correlated with TAFAZZIN mRNA expression in breast tumor tissues $(\mathrm{n}=45)$. (E) Illustration depicting the role of miR-125a-5p in regulating TAFAZZIN expression in the EMT, proliferation and apoptosis in breast cancer cells. Data are shown as the mean $\pm \mathrm{SD}$. Similar results were obtained from three independent experiments. ${ }^{*} \mathrm{P}<0.05$, as obtained via unpaired Student's $t$-test. MPG, Miller and Payne Grading; miR, microRNA; TAFAZZIN, tafazzin phospholipid-lysophospholipid transacylases; EMT, epithelial-mesenchymal transition; TG2, Transglutaminase 2 .

the activity of caspase- 3 and serves an important role in the anti-apoptosis in vivo, as shown using xenografts in athymic mice (22). EMT is a process that controls the acquisition of drug resistance. In the current research, transfection with miR-125a-5p suppressed the proliferation and increased the apoptosis of breast cancer cells in vitro. All these observations indicated that miR-125a-5p could resensitize drug-resistant breast cancer cells by suppressing EMT.

miR-125a-5p downregulated the expression levels of PCNA and Bcl-2, essential markers of cell proliferation and apoptosis (23), enhanced caspase-3 activity, increased pro-apoptotic protein Bax expression and decreased anti-apoptotic Bcl-2 expression. Suppression of miR-125a-5p downregulated caspase-3 activation, reduced Bax expression and upregulated anti-apoptotic Bcl-2 expression $(24,25)$. Furthermore, miR-125a-5p upregulates caspase-3 activation and suppresses in vitro cancer cell proliferation and migration in DU145 and VCaP cells (26). It has been shown that miR-125a-5p mimics enhanced the apoptotic rate and cleaved caspase-3 expression in mouse granulosa cells (27). Moreover, 
miR-125a-3p upregulation reduced Doc chemoresistance by regulating the BRCA1 DNA repair associated signaling in breast cancer cells (28).

These results indicated that the miR-125a-5p/TAFAZZIN axis is associated with drug resistance in breast cancer cells, and the combination of miR-125a-5p and Adr/Doc treatment is a potential therapeutic strategy to treat drug-resistant breast cancer.

miR-125a-5p can bind to 3'-UTR of TAFAZZIN to directly inhibit its expression in ovarian cancer (13). In the present study, reporter plasmids carrying wild-type and mutant TAFAZZIN 3'-UTR were constructed to further examine whether miR-125a-5p directly binds to TAFAZZIN in MCF-7/Adr cells. The transfection of miR-125a-5p mimic reduced the luciferase activity of TAFAZZIN 3'-UTR-wild-type but not of TAFAZZIN 3'-UTR-mutant in MCF7/Adr cells. Thus, miR-125a-5p may directly inhibit TAFAZZIN expression to modulate drug sensitivity in MCF-7/Adr cells. Dual-luciferase assay results also demonstrated that TAFAZZIN may be targeted by miR-125a-5p in MCF-7/Adr cells. Moreover, TAFAZZIN expression was decreased significantly after the MCF-7/Adr cells were transfected with miR-125a-5p.

In the current study, the western blot analysis revealed that TAFAZZIN knockdown downregulated TAFAZZIN, TG2 and AKT expression. TAFAZZIN also regulates downstream TGM2, a promising therapeutic target in the treatment of glaucoma, in human trabecular meshwork cells $(29,30)$. TG2 activates TAFAZZIN in pancreatic ductal adenocarcinoma cells (30). Suppressing TAFAZZIN can downregulate the expression level of AKT, and elevating TAFAZZIN can increase the phosphorylation of AKT (31). TAFAZZIN is regulated by the PI3K/AKT pathway (32). Furthermore, miR-125a-5p controls the expression levels of the important factors involved in AKT pathways in cervical cancer (33). Suppressing TGM2 expression can promote meningioma cell death by reducing AKT phosphorylation and caspase-3 (34), while AKT activation may drive normal breast mammary epithelial MCF10A cells into EMT via TG2 signaling (35). Moreover, TGM2 silencing can suppress AKT activation in the Saos2-cIS-R cells (36). All these data suggest that the reduced expression of TG2(TGM2)/AKT may promote the drug sensitivity of cancer cells via EMT reversal.

The current western blotting results indicated that TAFAZZIN knockdown activated caspase-3, increased Bax expression and downregulated TAFAZZIN, TG2, p-AKT, $\mathrm{N}$-cadherin, vimentin and PCNA expression. These data suggested that TAFAZZIN knockdown inhibited the EMT and drug resistance of MCF7/Adr cells. Suppressing TAFAZZIN can activate caspase-3 and promote apoptosis in MCF-7/Adr breast cancer cells. TAFAZZIN also upregulated the expression level of Bcl-2, reduced Bax expression and activated the PI3K/AKT pathway, revealing its important role in cell proliferation and apoptosis (37). TAFAZZIN also inhibits cell apoptosis and promotes the cell proliferation, migration, invasion and EMT of multiple human cancer types (32). In addition, TAFAZZIN oncogenic activities can promote the aggressiveness of pancreatic cancer (38), while its increased activation significantly promotes EMT and the acquisition of cancer stem cell-like traits in breast cancer cells $(39,40)$. TAFAZZIN also promotes hepatocyte proliferation and suppresses cell death after liver injury (41). Furthermore, blocking TAFAZZIN signaling pathway restores drug sensitivity in non-small cell lung cancer $(42,43)$.

The present study identified that TAFAZZIN was important for drug resistance and may be a potential therapeutic target for breast carcinoma. A relationship between TAFAZZIN and drug resistance in breast cancer was observed. For instance, TAFAZZIN regulated the expression levels of EMT-, proliferation- and apoptosis-related markers of MCF7/Adr cells. The dual-luciferase reporter assay results indicated that miR-125a-5p mimics significantly reduced the luciferase activity of TAFAZZIN 3'-UTR. Western blot analysis results also suggested that miR-125a-5p downregulated TAFAZZIN expression in MCF7/Adr cells. Thus, the effect of miR-125a-5p on EMT, proliferation and apoptosis may be associated with the expression of EMT-, proliferation- and apoptosis-related markers via TAFAZZIN downregulation. This finding suggested that miR-125a-5p could affect the expression of all three types of markers by negatively regulating TAFAZZIN signaling and, thus, inhibit EMT and proliferation and promote apoptosis.

In conclusion, the present study provided evidence that miR-125a-5p reversed EMT and restored drug sensitivity by negatively regulating TAFAZZIN signaling in breast cancer. The results revealed a relationship between EMT and drug resistance, such as the important roles of EMT in the regulation of drug resistance in biological processes. miR-125a-5p downregulated the expression level of TAFAZZIN, reversed EMT, suppressed proliferation and increased the apoptotic rates of breast cancer cells. TAFAZZIN knockdown regulated the EMT-, proliferation- and apoptosis-related gene and protein expression levels in breast cancer. High miR-125a-5p expression and decreased TAFAZZIN mRNA expression were observed in breast tumors from patients who achieved a chemotherapy response, and opposite results were found in those with no response. In vitro and in vivo experiments revealed that miR-125a-5p reversed EMT and restored drug sensitivity by targeting TAFAZZIN in patients with breast cancer. Therefore, miR-125a-5p has potential as a novel therapeutic target in breast cancer treatment. In vitro experiments using various breast cancer cell lines and further prospective clinical trials on this topic are required to elucidate how the reduction of miR-125a-5p and TAFAZZIN cause drug resistance, and whether miR-125a-5p and TAFAZZIN could predict the treatment efficacy of $\mathrm{Adr} / \mathrm{Doc}$ for patients with breast cancer.

\section{Acknowledgements}

Not applicable.

\section{Funding}

This study was supported by the Foundation item: Natural Science Foundation of Jiangxi Province of China (grant no. 20181BAB205054).

\section{Availability of data and materials}

The datasets used and/or analyzed during the current study are available from the corresponding author on reasonable request. 


\section{Authors' contributions}

DL, LC, XZ, YW, CH, JL, FH and WH conducted the experimental work and data collection. DL and WH designed the study, and performed the analysis and interpretation of data. DL and WH confirm the authenticity of all the raw data. All authors read and approved the final manuscript.

\section{Ethics approval and consent to participate}

This study was approved by the Ethics Committee of Jiangxi Provincial Cancer Hospital (approval no. 20180314; Nanchang, China). Written informed consent was obtained from all participants prior to experiments.

\section{Patient consent for publication}

Not applicable.

\section{Competing interests}

The authors declare that they have no competing interests.

\section{References}

1. Siegel RL, Miller KD and Jemal A: Cancer statistics, 2020. CA Cancer J Clin 70: 7-30, 2020

2. Zaheed M, Wilcken N, Willson ML, O'Connell DL and Goodwin A: Sequencing of anthracyclines and taxanes in neoadjuvant and adjuvant therapy for early breast cancer. Cochrane Database Syst Rev 2: CD012873, 2019.

3. Kumar S, Nandi A, Singh S, Regulapati R, Li N, Tobias JW, Siebel CW, Blanco MA, Klein-Szanto AJ, Lengner C, et al: Dll1+ quiescent tumor stem cells drive chemoresistance in breast cancer through NF- $\kappa$ B survival pathway. Nat Commun 18: 432, 2021.

4. Khordadmehr M, Shahbazi R, Sadreddini S and Baradaran B: miR-193: A new weapon against cancer. J Cell Physiol 234: 16861-16872, 2019.

5. Zhang YM, Wu QM, Chang LY and Liu JC: miR-34a and miR-125a-5p inhibit proliferation and metastasis but induce apoptosis in hepatocellular carcinoma cells via repressing the MACC1-mediated PI3K/AKT/mTOR pathway. Neoplasma 67: 1042-1053, 2020.

6. Xu X, Tao Y, Niu Y, Wang Z, Zhang C, Yu Y and Ma L: miR-125a-5p inhibits tumorigenesis in hepatocellular carcinoma Aging (Albany NY) 11: 7639-7662, 2019.

7. Vo DT, Karanam NK, Ding L, Saha D, Yordy JS, Giri U, Heymach JV and Story MD: miR-125a-5p functions as tumor suppressor microRNA and is a marker of locoregional recurrence and poor prognosis in head and neck cancer. Neoplasia 21 849-862, 2019.

8. Chen Y, Han H, Seo G, Vargas RE, Yang B, Chuc K, Zhao H and Wang W: Systematic analysis of the hippo pathway organization and oncogenic alteration in evolution. Sci Rep 10: 3173, 2020.

9. Ma S, Meng Z, Chen R and Guan KL: The hippo pathway: Biology and pathophysiology. Ann Rev Biochem 88: 577-604 2019.

10. Moroishi T, Hansen CG and Guan KL: The emerging roles of YAP and TAZ in cancer. Nat Rev Cancer 15: 73-79, 2015.

11. Ma W, Cui Y, Liu M, Tan Z and Jiang Y: Downregulation of miR-125b promotes resistance of glioma cells to TRAIL through overexpression of Tafazzin which is a mitochondrial protein Aging (Albany NY) 11: 2670-2680, 2019.

12. Kriz V and Korinek V: Wnt, RSPO and hippo signalling in the intestine and intestinal stem cells. Genes (Basel) 9: 20, 2018.

13. Cao Y, Shen T, Zhang C, Zhang QH and Zhang ZQ: MiR-125a-5p inhibits EMT of ovarian cancer cells by regulating TAZ/EGFR signaling pathway. Eur Rev Med Pharmacol Sci 23: 8249-8256, 2019.

14. Yang M, Tang X, Wang Z, Wu X, Tang D and Wang D: miR-125 inhibits colorectal cancer proliferation and invasion by targeting TAZ. Biosci Rep 39: BSR20190193, 2019.
15. He W, Sun Z and Liu Z: Silencing of TGM2 reverses epithelial to mesenchymal transition and modulates the chemosensitivity of breast cancer to docetaxel. Exp Ther Med 10: 1413-1418, 2015.

16. $\mathrm{Gu} \mathrm{M}$ and Shen $\mathrm{C}$ : Novel cancer cell lines derived from primary breast tumors in Chinese patients. Am J Transl Res 10: 3956-3968, 2018.

17. Shen C, Gu M, Liang D, Miao L, Hu L, Zheng C and Chen J: Establishment and characterization of three new human breast cancer cell lines derived from Chinese breast cancer tissues. Cancer Cell Int 9: 2, 2009.

18. Livak KJ and Schmittgen TD: Analysis of relative gene expression data using real-time quantitative PCR and the 2(-Delta Delta C(T)) method. Methods 25: 402-408, 2001.

19. Yun H, Shi R, Yang Q, Zhang X, Wang Y, Zhou X and Mu K: Over expression of hRad9 protein correlates with reduced chemosensitivity in breast cancer with administration of neoadjuvant chemotherapy. Sci Rep 4: 7548, 2014.

20. Ogston KN, Miller ID, Payne S, Hutcheon AW, Sarkar TK, Smith I, Schofield A and Heys SD: A new histological grading system to assess response of breast cancers to primary chemotherapy: Prognostic significance and survival. Breast 12: 320-327, 2003 .

21. Luo J, Yao JF, Deng XF, Zheng XD, Jia M, Wang YQ, Huang Y and Zhu JH: 14, 15-EET induces breast cancer cell EMT and cisplatin resistance by up-regulating integrin $\alpha v \beta 3$ and activating FAK/PI3K/AKT signaling. J Exp Clin Cancer Res 9: 23, 2018.

22. Jang GY, Jeon JH, Cho SY, Shin DM, Kim CW, Jeong EM, Bae HC, Kim TW, Lee SH, Choi Y, et al: Transglutaminase 2 suppresses apoptosis by modulating caspase 3 and NF-kappaB activity in hypoxic tumor cells. Oncogene 21: 356-367, 2010.

23. Cai Z, Li J, Zhuang Q, Zhang X, Yuan A, Shen L, Kang K, Qu B, Tang Y, Pu J, et : MiR-125a-5p ameliorates monocrotaline-induced pulmonary arterial hypertension by targeting the TGF- $\beta 1$ and IL-6/STAT3 signaling pathways. Exp Mol Med 27: $1-11,2018$.

24. Li Z, Jiang J, Tian L, Li X, Chen J, Li S, Li C and Yang Z: A plasma mir-125a-5p as a novel biomarker for Kawasaki disease and induces apoptosis in HUVECs. PLoS One 3: e0175407, 2017.

25. Wang LB, Feng L, He J, Liu B and Sun JG: MiR-125a-5p inhibits the proliferation and invasion of breast cancer cells and induces apoptosis by targeting GAB2. Math Biosci Eng 29: 6923-6933, 2019.

26. Fu Y and Cao F: MicroRNA-125a-5p regulates cancer cell proliferation and migration through NAIF1 in prostate carcinoma. Onco Targets Ther 17: 3827-3835, 2015.

27. Wang C, Li D, Zhang S, Xing Y, Gao Y and Wu J: MicroRNA-125a-5p induces mouse granulosa cell apoptosis by targeting signal transducer and activator of transcription 3 . Menopause 23: 100-107, 2016.

28. Xu X, Lv YG, Yan CY, Yi J and Ling R: Enforced expression of hsa-miR-125a-3p in breast cancer cells potentiates docetaxel sensitivity via modulation of BRCA1 signaling. Biochem Biophys Res Commun 8: 893-900, 2016.

29. Raghunathan VK, Morgan JT, Dreier B, Reilly CM, Thomasy SM, Wood JA, Ly I, Tuyen BC, Hughbanks M, Murphy CJ and Russell P: Role of substratum stiffness in modulating genes associated with extracellular matrix and mechanotransducers YAP and TAZ. Invest Ophthalmol Vis Sci 14: 378-386, 2013.

30. Lee J, Condello S, Yakubov B, Emerson R, Caperell-Grant A, Hitomi K, Xie J and Matei D: Tissue transglutaminase mediated tumor-stroma interaction promotes pancreatic cancer progression. Clin Cancer Res 1: 4482-4493, 2015.

31. Xu W, Wei Y, Li Y, Yin Y, Yuan W, Yang Y, Zhao W and Wu J: TAZ inhibition restores sensitivity of cisplatin via AKT/mTOR signaling in lung adenocarcinoma. Oncol Rep 38: 1815-1821, 2017.

32. Zhou X and Lei QY: Regulation of TAZ in cancer. Protein Cell 7: 548-561, 2016.

33. Cao Q, Wang N, Ren L, Tian J, Yang S and Cheng H: miR-125a-5p post-transcriptionally suppresses GALNT7 to inhibit proliferation and invasion in cervical cancer cells via the EGFR/PI3K/AKT pathway. Cancer Cell Int 10: 117, 2020.

34. Huang YC, Wei KC, Chang CN, Chen PY, Hsu PW, Chen CP, Lu CS, Wang HL, Gutmann DH and Yeh TH: Transglutaminase 2 expression is increased as a function of malignancy grade and negatively regulates cell growth in meningioma. PLoS One 23 : e108228, 2014.

35. Kumar A, Xu J, Brady S, Gao H, Yu D, Reuben J and Mehta K: Tissue transglutaminase promotes drug resistance and invasion by inducing mesenchymal transition in mammary epithelial cells. PLoS One 12: e13390, 2010. 
36. Li C, Cai J, Ge F and Wang G: TGM2 knockdown reverses cisplatin chemoresistance in osteosarcoma. Int J Mol Med 42: 1799-1808, 2018

37. Wang S, Ma K, Chen L, Zhu H, Liang S, Liu M and Xu N: TAZ promotes cell growth and inhibits celastrol-induced cell apoptosis. Biosci Rep 29: e00386, 2016.

38. Santoro R, Zanotto M, Carbone C, Piro G, Tortora G and Melisi D: MEKK3 sustains EMT and stemness in pancreatic cancer by regulating YAP and TAZ transcriptional activity. Anticancer Res 38: 1937-1946, 2018.

39. Piccolo S, Dupont S and Cordenonsi M: The biology of YAP/TAZ: Hippo signaling and beyond. Physiol Rev 94: 1287-1312, 2014.

40. Bhandari A, Guan Y, Xia E, Huang Q and Chen Y: VASN promotes YAP/TAZ and EMT pathway in thyroid carcinogenesis in vitro. Am J Transl Res 15: 3589-3599, 2019.
41. Kim AR, Park JI, Oh HT, Kim KM, Hwang JH, Jeong MG, Kim EH, Hwang ES and Hong JH: TAZ stimulates liver regeneration through interleukin-6-induced hepatocyte proliferation and inhibition of cell death after liver injury. FASEB J 33: 5914-5923, 2019.

42. Gobbi G, Donati B, Do Valle IF, Reggiani F, Torricelli F, Remondini D, Castellani G, Ambrosetti DC, Ciarrocchi A and Sancisi V: The Hippo pathway modulates resistance to BET proteins inhibitors in lung cancer cells. Oncogene 38: 6801-6817, 2019.

43. Nguyen CDK and Yi C: YAP/TAZ signaling and resistance to cancer therapy. Trends Cancer 5: 283-296, 2019.

This work is licensed under a Creative Commons Attribution-NonCommercial-NoDerivatives 4.0 International (CC BY-NC-ND 4.0) License. 